\title{
Diploma verplicht per
1 september 2018?
}

Een aantal jaren geleden kondigde de KNMT aan dat een mbo-diploma per 1 september 2018 verplicht zou moeten zijn. Hoe wordt deze regel geïmplementeerd vroeg een lezeres zich af. De redactie ging navraag doen bij de KNMT en ANT.

\section{Door Maria de Vries}

B eleidsadviseur KNMT Carla Schenkeveld kwam met de volgende reactie. "Zorg verlenen doe je samen. Vandaar dat de KNMT de deskundigheid van het team als continu punt van aandacht heeft in haar beleid. De KNMT vindt dat er minimumeisen moeten worden gesteld aan de opleiding van tandartsassistenten. Met het instellen van de mbo-opleiding Tandartsassistent als basisniveau, wordt het opleidingsniveau van tandartsassistenten eenduidig, transparant en inzichtelijk voor de patiënt.” Op mijn vraag hoe hier toezicht op wordt gehouden antwoordde Schenkeveld: "Toezicht houden is aan de Inspectie Gezondheidszorg en Jeugd (IGJ) en we weten dat de Inspectie het standpunt van de KNMT hieromtrent omarmt."

Dit betekent dat er drie keuzemogelijkheden zijn om na 1 september 2018 te solliciteren bij een werkgever die is aangesloten bij de KNMT: 1.Je bent tandartsassistent met een mbo-diploma Tandartsassistent.

2.Je bent een ongediplomeerde tandartsassistent uit de al werkende groep tandartsassistenten met een arbeidsovereenkomst daterend voor 1 september 2018

3. Je bent ongediplomeerd en nieuw op de arbeidsmarkt. In dat geval moet je als assistent direct bij aanvang van het dienstverband in opleiding voor het mbo-diploma Tandartsassistent.

De opleiding tot tandartsassistent moet een mbo-opleiding niveau 4 zijn. Er zijn verschillende mogelijkheden op een erkend mbo-diploma Tandartsassistent te behalen.
Zie hier voor www.knmt.nl/voor-patienten/beroep-tandartsassistent/bij-en-nascholing-tandartsassistent/opleiding

Tandarts Ravin Raktoe, secretaris van de ANT: "De ANT is niet tegen een mbo-4 opleiding, maar geen voorstander van een uniforme mbo4 opleidingseis voor ál het assisterend personeel. Voor een groot deel van de assistenten is dit gezien hun taken overbodig. Wij zien meer in opleidingen op maat, waarbij de werkzaamheden zijn ingedeeld in risicocategorieën. Zo kan iemand meer gericht worden opgeleid voor de specifieke werkzaamheden en is de bekwaamheid beter aantoonbaar. Gemotiveerde assistenten kunnen op deze manier bovendien sneller aan de slag zonder op onnodige drempels te stuiten. Variabele minimum opleidingseisen op basis van het tandheelkundig risico van werkzaamheden biedt voor iedereen meer kansen. En niet in de laatste plaats: voor de patiënt meer inzicht in de bekwaamheid van de assistent.

In 2015 en 2016 zijn hierover twee standpunten geformuleerd, namelijk Werkzaamheden assisterend personeel en Opleidingen Assisterend Personeel in de Tandartspraktijk, waarin we op basis van die risicoprofielen de structuur van een A, B en C diploma voorstellen. Het A diploma staat voor de omloop- en stoelassistent, B voor de preventieassistent en $\mathrm{C}$ voor de paro-assistent. Een modulaire opleiding: meer waar nodig, minder waar het kan. Zo sluit het opleidingsniveau beter aan op de werkzaamheden en verantwoordelijkheden in de praktijk en zijn de doorgroeimogelijkheden optimaal.” 